\title{
Areal Structure of Economy in East Germany after the Unification of Germany
}

\author{
Hiroshi SASAKI \\ Institute of Geoscience, University of Tsukuba, Tsukuba 305-8571, Japan
}

\begin{abstract}
Unification of Germany has put East Germany in the position of being a laboratory, a good example of areal changes in the world. At the time of unification the share of East Germany in the whole German GDP was only $7.2 \%$ in 1991, but owing to large transfers for East Germany and to the foreign investments, it became $10.9 \%$ in 1995 . Unification of the currency brought a favorable exchange rate $(1: 1)$ for East German, but it caused a weakening of the competitive power of East German industries on the world market. All state owned properties and enterprises were put under the control of Treuhandanstalt, which reprivatised, privatised or sold them to West German or foreign companies. Many profitable enterprises were bought as "fillet" by West German big companies and the rest as "fat and bone" by foreign companies, among which French, USA and British dominated. The areal structure of economy in East Germany was worked out by some geographers during the age of DDR (German Democratic Republic), but none have yet tried, because the time is not sufficient since the unification of Germany. The contrast between "Industrial South and Agricultural North" is very clear and rooted in natural conditions and in a long history. Five such economic regions may be distinguishable: agro-industrial region along Baltic coast, agricultural region on lowland in the Middle, mining and industrial region in the South, Sachsen=Thüringen industrial region, and Berlin.
\end{abstract}

Key words: unification of currency, Treuhandanstalt, foreign investment, transfers for East Germany

\section{Introduction}

The transformation processes of former socialistic countries were main themes in IGU Congress in Amsterdam in 1996. The aim of this report is to look back at the economic situation in East Germany, the former DDR = Deutsche Demokratische Republik, and to discuss the areal structure of its economy after the unification of Germany on 3rd Oct. 1990.

\section{Economic Situation of East Germany Directly after Unification}

Under the socialistic economic system, all means of production were under the control of state or cooperation $(\mathrm{VEB}=$ Volkseigener $\mathrm{Be}$ trieb or LPG $=$ Land wirtschaftliche Produktionsgenossenschaft). As a socialistic country, DDR endeavored to attain Autarkie (self-sufficient economy) and traded among COMECON
(Comunist Economic Conference=SEV). Gigantic industrial units known as Kombinat, which Walter Ulbricht called "socialistic Konzern", consisted of 15-30 enterprises and employed about 20,000 workers. Konbinat Roboton, a computer maker, had 68,000 workers.

\section{Economic Unification of East Germany with West Germany}

\section{Unification of currency}

On the 1st of July 1990 unification of currency was completed. The Federal Bank of Germany asserted the exchange of one East Mark into half a Deutsche Mark, but it was decided 1:1 for political reasons. West German politicians were all anxious about the big population inflow from East to West, because during four months from October 1989 to January 1990, 0.3 million people moved from East to West. The real exchange rate had been $1: 4$, so 
the East Mark was in reality raised $400 \%$. That benefited the private life of East German people, but has forced the enterprises in East Germany to loose competitive power on the world market.

\section{Destruction of economy in East Germany}

Destruction of COMECON and the cancellation order by West German enterprises have forced East German exports abruptly to cease. The number of unemployed amounted to 910,000 and Kurzarbeiter (short time worker) to 1.6 million. Discharge of military service and administration workers of DDR generated major unemployment amounting to 2.5 million less than one year after unification. The rate of unemployment in East Germany was $10.3 \%$ (6.3\% in West Germany) in 1991, 14.8\% (6.6) in $1992,15.8 \%(8.2)$ in $1993,16.0 \%(9.2)$ in 1994 and $14.0 \%(9.3)$ in 1995.

The profitable exchange rate $(1: 1)$ of currency enabled East Germans to buy western new and used cars, and in a few years after unification the former East German national car Trabant: "Trabi" disappeared to be a classic car. The wages of East German workers have been fixed about $70-80 \%$ of that of West, but industrial productivity in East Germany was $30 \%$ in 1991 and $53 \%$ in 1994. The disparity between wages and productivity became so large as to weaken the competitive power of East German industries on the world market.

The number of industrial workers in East Germany decreased from 1.64 million in 1991 to
0.63 million (39\% of 1991) in 1994. The largest decrease rate was experienced by the iron, textile and machine industries. Only the automobile industry has improved production: from 3.9 Mrd. (billion=a thousand millions) DM 1991 to 5.8 Mrd. DM 1992. Big investments were made: in Eisenach by Opel, in Mosel bei Zwickau by $\mathrm{VW}=$ Volkswagen, in Ludwigsfelde bei Berlin by Mercedes-Benz. One of the large obstacles to investment in East Germany was the complexity of landownership. Three times expropriations were carried out, by the Nazis, the Occuping army of the Soviet Union and DDR.

\section{Transfers for East Germany}

Transfers of public capital from West Germany to East Germany amounted to 1,043 Mrd. DM in the 7 years from 1991 to 1997 , which is as large as the Japanese general account of the national budget in 1997 (Table 1). The share of East Germany in the whole German GDP (gross domestic product) was only $7.2 \%$. So the federal government had to invest more than 120 Mrd. DM a year into East Germany. 75.6\% of that was carried by the federal budget. In such infrastructure as waterways, railways and roads $19.3 \%$ of transferred capital was invested, but the largest (25.2\%) portion was wasted for social and unemployment insurance.

German magazine "Der Spiegel" criticized: Support from West Germany was not used for the creation of infrastructure but wasted for the living costs of East German people.

In 5 years from 1991 to 95,625 Mrd. DM was

Table 1. Transfers for East Germany in Mrd. DM

\begin{tabular}{rrrr}
\hline & 1997 & $1991-97$ & $\%$ \\
\hline I. Federal Budget & 126 & 785 & 75.6 \\
1. Expenses to States & 17 & 160 & 15.3 \\
2. Expenses to people & 28 & 263 & 25.2 \\
$\quad$ (Social-, unemployment-insurance, Children allowance) & 37 & 201 & 19.3 \\
3. Other expenses (Waterway, road, railway etc.) & 52 & 39 & 3.7 \\
II. Other Benefit & & 122 & 11.7 \\
(Fund of Unification of Germany, EU, Annuity insurance etc) & 13 & 0.7 \\
III. Treuhandanstalt & 191 & 1,366 & 323 \\
IV. Retrenchment of tax & 53 & 31 \\
Sum & 138 & 1,043 & 100 \\
V. Back flow (income through taxes and administration costs) & & \\
\hline Total & & & \\
\hline
\end{tabular}


invested into East Germany by private companies, in the service sector $39.6 \%$ (72\% of which was immobile agents), in the production sector $35.9 \%$ (52\% of which was in manufacturing industries). Industrial investments, although earnestly desired, were only $19 \%$, as large as transportation and telecommunication sector.

\section{Treuhandanstalt}

Treuhandanstalt (national trust institution) was founded in 1990 to control the former state owned properties and enterprises, and was the world's biggest holding company in 1991, controlling 13,781 state owned enterprises and 10,652 small shops with 4 million workers. It has endeavored to privatise by selling them to foreign and West German companies or by reprivatizing (returning the socialized properties to former owners). Up to the dissolution of Treuhandanstalt in December 1994, it liquidated 3,525 enterprises, sold 2,679 enterprises to workers (Management Bayout $=\mathrm{MBO}$ ), 855 enterprises to foreign capital, and the rest to West German companies.

At the time of dissolution of Treuhandanstalt it had $275 \mathrm{Mr}$. DM debt and 100 enterprises left, which could not be sold. Former gigantic enterprise group called Kombinat was broken up into small enterprises: "fillet" enterprises and "fat and bone" enterprises. It is said that such "fillet" enterprises as Interflug (former national air carrier of DDR), Carl Zeiss, Roboton (computer maker group of DDR) were sold to West German companies, and only "fat and bone" enterprises were left to foreign capital. Interflug was taken over by Lufthansa, Carl Zeiss by the sister company Carl Zeiss Oberkochen. After the reduction of workers from 28,000 to 6,000 , Roboton was broken down into 21 enterprises, some of which were sold and some liquidated.

The symbol of socialism "EKO-iron" in Eisenhütenstadt should have been bought by Krupp, but the plan was cancelled owing to the management crisis of Krupp. Krupp closed also the iron enterprise in Oranienburg north of Berlin, which it had bought from Treuhandanstalt. Eko-iron was bought at last after many twists and turns by Belgium
Cockerill Sambre in January 1995.

In 1993 many West German companies began to negotiate with Treuhandanstalt for favorable conditions of investment and employment in East Germany. VW began to produce VW Golf at Mosel, $7 \mathrm{~km}$ north of Zwickau, by joining with IFA (East German Automobile Kombinat). VW was to produce 1,200 cars a day, but gave up the plan, because of opposition from the government of Niedersachsen, where the headquarter factory was located at Wolfsburg. The Niedersachsen government feared employment in Niedersachsen would decrease.

The reduction of production of VW Golf in Mosel brought Sachsen Automobil Werke (once produced Trabant until 1991) to a crisis, and it went into bankruptcy at the end of 1993. Because Sachsen Automobil Werke had VW Golf under subcontract of $\mathrm{VW}, \mathrm{VW}$ invested more in foreign subsidiary companies; SEAT in Spain and Škoda in Chez, rather than in East Germany. VW's subsidiary company Audi was to have built an automobile engine factory near Magdeburg, Sachsen-Anhalt, but it changed the plan to build it at Györ in the northwest of Hungary, where they produced 200 engines a day in August 1994, and planned to increase to 2,000 engines a day.

Other examples are the case of kali exploiting and shipbuilding enterprises of Treuhandanstalt. A West German kali exploiting company bought 4 kali enterprises from Treuhandanstalt under the condition of closing Bischofferode in the south of Harz massive mountains, which had the largest deficit. Of course the workers of Bischofferode resisted the liquidation of the enterprise with hunger strike. But the labor union of West German company also supported the attitude of company. A shipbuilding company in Bremen wanted to buy three shipbuilding enterprises of Treuhandanstalt. EU Committee gave warning again and again that the federal subsidiary might concentrate only on one shipbuilding company in Bremen. So a Norwegian shipbuilding company bought one in 1992 .

The industrial character of East and West Germany was similar, specialized in machines, electronic technology and chemicals. Before 
the unification of Germany both played a role in each economic world: western and COMECON. After the destruction of the iron curtain, both had to compete with each other on the same market. The vivisection of former DDR Kombinat by West Germany can be seen as a result of industrial struggle for existence.

DDR enterprises (VEB or Kombinat) were too big to be bought by foreign investors. Among foreign investors France, Switzerland, Great Britain, Austria, USA and the Netherlands were dominant (Table 2). France had been the leading foreign investor: $26.8 \%$ of the sum of investment, $16.9 \%$ of the number of employees and $25.8 \%$ of the sum of purchase price. Such leading companies in Europe as French Societé Nationale Elf Aquitaine and TOTAL, British Gas and British Industries Celenders Cables (BICC), Swiss ABB = Asea Brown Boveri AG (the biggest heavy manufacturing industry in Europe) bought some of the "fat and bone" Trauhandsanstalt enterprises and invested with their own strategy.

\section{Areal Structure of Economy in East Germany}

\section{Present situation of economy in East Germany}

About 5.2 millions people moved from DDR to West Germany and West Berlin in the 42 years from 1949 to 1990 , especially skilled and high-quality workers, which caused major damage to the economy of DDR. In the first wave of migration, until the construction of the Berlin wall (13. Aug. 1961), 200,000-300,000 people moved every year. The Berlin wall was constructed to prevent the outflow of workers from DDR. The second wave took place in the year of the destruction of the wall in 1989, when 388,000, and in 1990220,000 , moved from East to West. Such a rapid inflow into West Germany caused a rise of house rent. The share of cold house rent (without heating cost) in total house keeping costs has grown to $20.5 \%$ in $1990,21.0 \%$ in $1991,21.0 \%$ in 1992 $22.0 \%$ in $1993,23.8 \%$ in 1994 and 24\% in 1995. It had been growing also in East Germany to $4.0 \%$ in $1990,3.8 \%$ in $1991,12.4 \%$ in 1992 , $16.8 \%$ in $1993,16.9 \%$ in $1994,18 \%$ in 1995. This is one of the reasons why East German people are not completely satisfied with the unification of Germany.

The service sector is the biggest (30.2\% of GDP in 1995) economic branch in East Germany, although it is not as large as in West Germany (36.8\%). The public and official service sector has been very strong (24.6\% in 1991), reflecting the centralized socialistic regime. It was still $21.5 \%$ in 1995 , much higher than that of West Germany (13.4\%). The manufacturing industry sector was in third place (14.0\%),

Table 2. Top-Ten Foreign Investors (31 May 1994)

\begin{tabular}{lrrrr}
\hline & $\begin{array}{c}\text { Privatization } \\
\text { (number) }\end{array}$ & $\begin{array}{c}\text { Investment } \\
\text { consent } \\
\text { (Mio DM) }\end{array}$ & $\begin{array}{c}\text { Employment } \\
\text { consent } \\
\text { (person) }\end{array}$ & $\begin{array}{c}\text { Sales } \\
\text { (Mio DM) }\end{array}$ \\
\hline France & 88 & 5,459 & 25,543 & 1,447 \\
Switzerland & 135 & 1,197 & 19,580 & 458 \\
United Kingdom & 126 & 2,247 & 17,740 & 984 \\
Canada & 10 & 1,848 & 16,955 & 35 \\
Austria & 102 & 1,028 & 16,598 & 296 \\
USA & 79 & 3,092 & 14,285 & 724 \\
Netherland & 94 & 1,191 & 10,367 & 392 \\
Italy & 37 & 670 & 4,847 & 322 \\
Denmark & 28 & 547 & 3,217 & 340 \\
Luxemburg & 12 & 406 & 2,208 & 276 \\
Others & 133 & 2,753 & 20,073 & 349 \\
\hline Total & 844 & 20,440 & 151,413 & 5,622 \\
\hline
\end{tabular}

(Treuhandanstalt Zentrales Controlling) (Verzeichnis ausländischer Investoren 5/94) 
which was once $44 \%$ in 1989 , but now much less than that of West Germany (26.4\%). The unification of Germany has completely destroyed the industries in East Germany. Building industry sector (17.6\%) is now in second place and booming in the age of capital construction and is much higher than that in West Germany (5.3\%). Even the index of productivity (100 in 1991) of the manufacturing industry showed 92 in 1992, 105 in 1993, 123 in 1994, 141 in 1995, the automobile industry shows the highest, 198 in 1995.

Monthly income of a worker in East Germany in 1991 was $49 \%$ of that in West Germany, increasing to $71 \%$ in 1995 . The disparity of wages in East and West Germany depended mostly on less additional wages in East Germany as dependents money and Christmas money. Monthly expenditure of a family of 4 members in East Germany (3,364 DM in 1995) was $82 \%$ of that in West Germany, but it was $65 \%$ in 1991. GDP of East Germany was 208 Mrd. DM in $1991,7.2 \%$ of the whole of Germany, but it grew to 376 Mrd. DM in 1995, 10.9\%, close to the $11 \%$ of total investment in East Germany. The productivity per employee in East Germany was 31.0 (West Germany =100) 1991, 43.1 in 1992, 51.6 in 1993, 54.3 in 1994, 55.2 in 1995.

Ministry of Economy of Federal Republic of Germany summarized the economy of East Germany as follows (Aufbau Ost 1997):

1. Since the unification of Germany the greatest increase of social and economic development under the social market economy (Soziale Marktwirtschaft) has been seen. It is said that economic recovery in East Germany has proceeded faster than the economic wonder (Wirtschaftswunder) of West Germany in the 1950s. One of the most important reasons for this economicdevelopment was investment dynamics.

2. But it is still on the half way to develop the economy with its own efforts and to keep employment.

3. A large problem which remains is to eliminate unemployment (unemployment rate was 15.0\% in August 1996), and to develop infrastructure, especially at the community level.

4. The most important is for employers and employees to raise productivity.

\section{Industries in Berlin}

The unification of Germany has brought the industries in both Berlins to a crisis. West Berlin lost the various kinds of more advantageous taxation on industries during the period of Cold War: "isolated island in a red sea". Only the service sectors have made an increase and the structure of population in West Berlin has become a little younger. The predominant situation of the electric industry and banking in Berlin over the whole of Germany in the golden 1920 s has been lost. The position has been replaced by Frankfurt am Main during the 45 years after the Second World War.

The city of Berlin has endeavored to make a new scientific and technological center at Johannisthal Adlershof (former military ground) in Berlin Ost and the city intends to build high technical industries there. The central district of Berlin is now under construction to build the new district of central government by 2000 . The location of Berlin is going to be an economic center of cooperation with former socialistic countries, especially Poland.

\section{Toy industry at Sonneberg in Thüringer Wald, Thüringen}

Since the 17th century the Sonneberg area has made the largest toy manufacturing area at the south-western slope of Thüringer Wald forests, using the plenty of forest woods. The merchants of Nürnberg sold toys not only to Europe but also to the whole world. Around 1900 the toy industry reached its peak, with about 36,000 industrial workers, $37 \%$ of which was engaged in the toy industry, followed by the pottery and porcelain industry (24\%) and the glass industry (21\%). The largest importers of toys manufactured in the Sonneberg area were England and the USA. So an American consulate and the trade representative of an American company (Woolworth) were established at Sonneberg.

The effects of the world economic crisis in 1929 on Sonneberg were larger and longer lasting than on other areas in Germany. Under the Nazi regime the toy industries were converted to military industries. After the Second World 
War they were converted again to industries for daily necessities. Under the socialist economic system, many small toy factories were integrated into 5 large state owned companies and a Kombinat. After the unification of Germany in 1990, they were converted again to capitalistic private companies and have suffered now under the social market economic system.

\section{Musical instruments industry in Vogtland, Sachsen}

Vogtland is situated between Thüringerwald, Frankenwald and Erzgebirge and borders Czech and Bayern. The musical instruments industry was introduced by Czech people in about 1650 with the recatholic movement in Bohemia. The industry reached its peak year just before the First World War when a Charge d'Affairs of the American consulate was settled in Markneukirchen, Landkreis Klingenthal, to import musical instruments. During the DDR age, most musical instruments were exported to socialistic countries.

The center of the industry is Markneukirchen with the population of 7,612 in 1993 . There were 131 makers of musical instruments with 952 workers. Almost all makers were small private handicrafts with one or two workers.

Since the unification of Germany the name of Vogtland is not so known among western world and the former socialistic markets have been destroyed by the lack of foreign-exchange holdings in those countries. Vogltland makers are now suffering severely from the economic crisis, and are looking forward to find new ways of making a living. Vogtland musical instruments makers must be confronted not only with keen competition from other inland makers, but also with those in Czech, Japan and America.

\section{Economic regions in East Germany}

Because of a short period since the unification of Germany, nobody has yet tried to work out this theme. In "Die Fünf Neuen Bundesländer" published in 1993, are four economic maps of DDR. which all reveal the same pattern: industrialized South and agricultural North. The new maps after unification are published by
Bundesforschungsanstalt für Länderkunde und Raumordnung 1992 (Fig. 1). One map shows the number of industrial workers in 1000 engaged people in 1989 by Kreis. Sachsen and Thüringen show the highest (more than 380/ 1000).

From 1990 to June 1995, 1,240,000 legal persons (corporations) were newly registered in East Germany and 534,000 were erased, so Saldo remain 706,000 . Out of 686,000 registered corporations, Sachsen has the largest number (29.6\%) and then Thüringen (17.2\%). The investment in East Germany by ERP (European Recovery Program, former Marshall Fund) and GA (Gemeinschaftsaufgabe "Verbesserung der regional Wirtschaftsstruktur") from 1990 to June 1996 was $292 \mathrm{Mrd}$. DM. The largest investment receiver was Sachsen (28.3\%), and the least was Berlin Ost (3.9\%), followed by Mecklenburg-Vorpommern (11.8\%). The creation of new corporations and new investment were strongly oriented to the South: "High in the South, Low in the North".

I set up the economic regions in East Germany as follows:

1. Agro-industrial region along Baltic coast

Hilly lake districts covered by moraine of Würm ice age have been planted with forage crops (rye, barley), upon which pigs are reared. 2. Agricultural region on lowland in the Middle

In the areas north of Magdeburg-Cottbus line except Berlin, rye and potatoes are mainly cultivated. On the fertile Magdeburger Börde wheat and sugar beet are planted.

3. Mining and industrial region in the South

Kali, Salt around Harz massive mountains and brown coal are the basis of this energy and chemical industrial region. Here live $40 \%$ of the East German population. Under the DDR regime no protection was taken agaist the contamination of environment. So the old gigantic chemical factories became superannuated and are being removed around Bitterfeld, Wittenberg, Leuna and Cottbus.

\section{Sachsen-Thüringen industrial region}

Started from handicraft manufacturing in and around the mountains. Industrial revolution of Germany started from Chemnitz, called German Manchester, to the West till Franken 


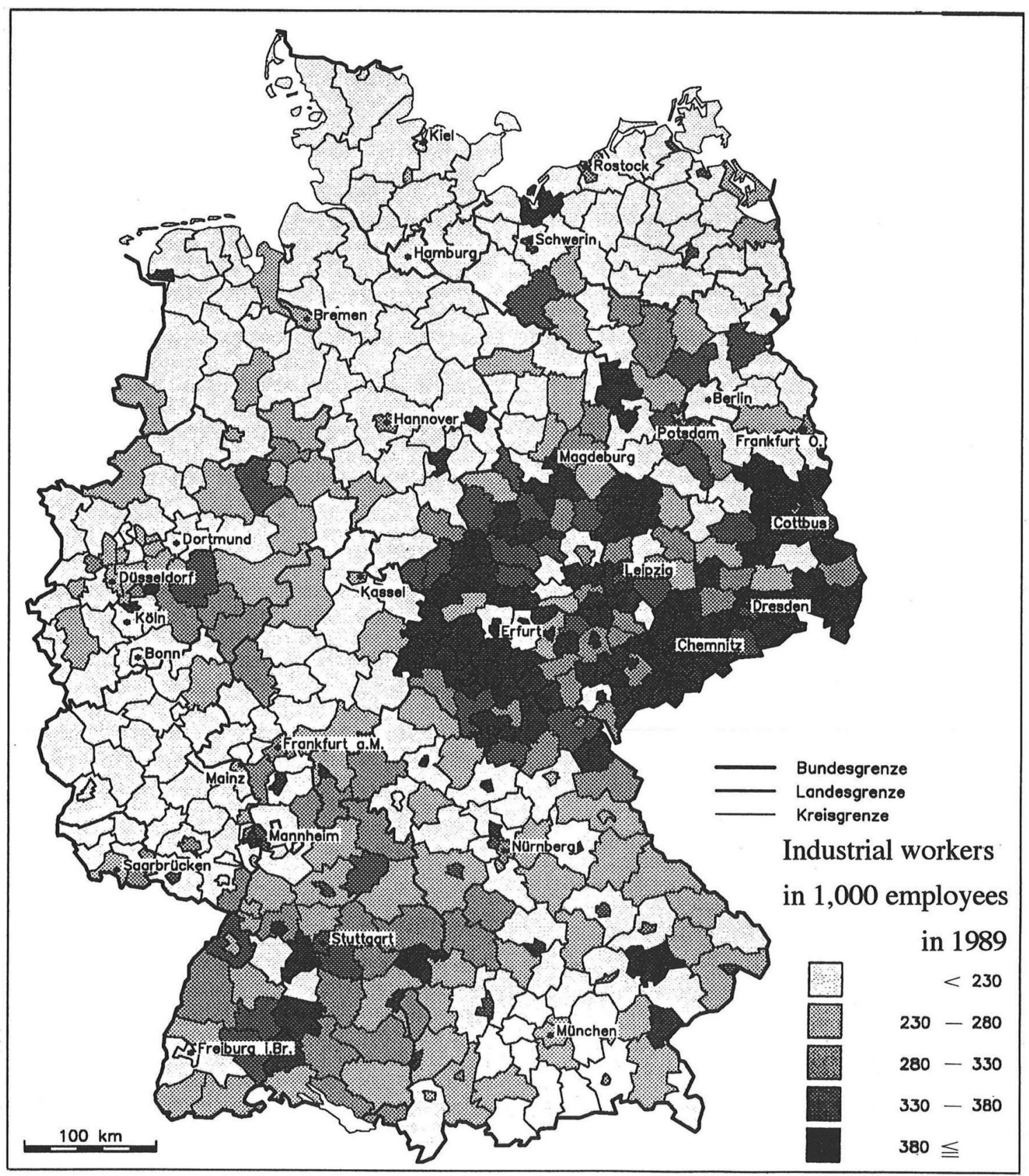

Figure 1. Number of industrial workers in 1,000 employees (15-65 years old) in 1989. Source: BfLR Bonn 1992

(Hof, Münchberg, Bayreuth etc.). Toys in Sonneberg, glass ware in Lauscha and Arnstadt, Chinaware in Meißen, musical instruments in Klingenthal, house ware and metal ware in Schmalkalden, Büreau ware in Zella-Mehlis remained there till now as traditional in- dustries. But modern big industries are also located: Volkswagen at Mosel north of Zwickau, Opel in Eisenach, Carl Zeiss Oberkochen in Jana.

\section{Berlin}

Siemens, AEG, Borsig were the symbols of 
Berliner industries. Today these industries face great difficulties. The city authority intends to create hightechnology industries based upon the enormous potential of many scientific research institutions.

The economic regions in East Germany depend deeply on the natural environments, the distribution of natural resouces and the traditional industrial technics.

\section{Conclusions}

1. At the time of unification in 1990, GDP of East Germany was only $7.2 \%$ of the whole of Germany, but it reached $10.9 \%$ by 1995 .

2. The favorable exchange rate for East German people at the unification of the currencey money has weakened the competitive power of East German industries on the world market.

3. Former state owned enterprises of DDR were all put under the control of Treuhandanstalt to sell, to privatise or liquidate. Important foreign investors in East Germany were France, USA and Great Britain.

4. Active capital transfers into East Germany by federal government and private companies have gradually revived the East German economy.

5. Economic development of industries after the unification of Germany is different by branches of industry and area.

6. The contrast between the South and the North in the areal structure of the economy of East Germany is very clear and is rooted in its nature and long history. The south abounds in mineral ore, woods, skill of workers and economic systems, on which have developed various kinds of traditional and modern industries.

7. It is still difficult to evaluate the industrial areas of Schwedt and Eisenhüttenstadt along the Oder river and the brown coal fields on both sides of Elbe river, which were all developed under the regime of DDR.

(Received May 30, 1997)

(Accepted Oct. 10, 1997)

\section{References}

Bundesministerium für Wirtschaft 1995. Aufbau Ost. Bericht der Bundesregierung. Nr. 382. Bonn.

Bundesministerium für Wirtschaft 1996. Aufbau Ost. Bericht der Bundesregierung. Nr. 407. Bonn.

Bundesministerium für Wirtschaft 1996. Wirtschaft in Zahlen '96, Bonn.

Eckart, K. 1989. DDR Neubearbeitung. Stuttgart: Klett. Golz, H. G. 1996. Länderfüsion gescheitert. Deutschland Archiv 29: 349-342.

Herrmann, J. 1987. Berlin. Berlin: Akademie-Verlag.

Hofmeister, B. 1975. Bundesrepublik Deutschland und Berlin. Darmstadt: Wissenschaftliche Buchgesellschaft.

Hofmeister, B., Pachur, H. J. and Pape, C. 1985. Berlin Beiträge zur Geographie eines Großstadtraumes. Festschrift zum 45. Deutschen Geographentag. Berlin: Dietrich Reimer Verlag.

Jones, A. 1995. The New Germany. Chichester: Wiley.

Kohl, H., Marcinek, J., and Nitz, B. 1986. Geography of the German Democratic Republic. Gotha: VEB Hermann Haack.

Morita, K. ed. 1992. Chuutouou (Middle East Europe). Tokyo: Doubunsha. (J)

Mogi, K., Shinoda, T., and Sakuma, K. 1996. Touitugo 5 nenno doitsuto tououkeizai (Germany after 5 years of unification and economy in East Europe). Bank of Tokyo Economic Quarterly 1: 86-134. (J)

Moser, H. ed. 1992. Berlin-report. Wiesbaden: Gabler. Presse- und Informationsamt des Landes Berlin 1992. Berlin Handbuch. Berlin: FAB Verlag.

Rutz, W., Scherf, K. and Strenz, W. 1993. Die Fünf Neuen Bundesländer. Darmstadt: Wissenschaftliche Buchgesellschaft.

Sasaki, H. 1977. Gendainodoitsu (Modern Germany). Tokyo: Ninomiyashoten. (J)

Sasaki, H. 1980. Bonn-from roman fortress to federal capital. In Toshikeiseino chiritekikiban, ed. Fumio, T., 158-170. Tokyo: Ninomiyashoten. (J)

Sasaki, H. 1993. Restructuring of Administration Area and Academic Research System in Former East Germany after Unification. Tsukuba Studies in Human Geography 17: 107-130. (JE)

Sasaki, H. 1994. Areal Structure and Industrial Policy in Unified Berlin. Tsukuba Studies in Human Geography. 18: 163-190. (JE)

Sasaki, H. 1994. Toy Industry at Sonneberg in Thüringer Wald, Germany. Area Studies Tsukuba 12: 1-26. (JE)

Sasaki, H. 1995. Changes of Musical Instruments Industry in Vogtland, Sachsen. Tsukuba Studies in Human Geography 19: 21-46. (JE)

Sasaki, H. 1997. Economic Situation in Berlin after the Unification of Germany. Area Studies Tsukuba 15: 147-172. (JE)

Scharfe, W. 1987. Berlin und seine Umgebung im Kartenbild. Berlin: Colloquium Verlag. 
Scherf, K. and Viehrig, H. eds. 1995. Berlin und Brandenburg. Gotha: Justusperthes.

Senatsverwaltung für Stadtentwicklung und Umweltschutz 1993. Flächennutzungsplan Berlin. Erläuterungsberich. Berlin.

Senatsverwaltung für Wirtschaft und Betriebe 1996. Wirtschaftsbericht Berlin 1996. Berlin.

Smyser, W. R. 1992. The economy of united Germany. New York. Translated by Terao, M. Tokyo: Nihonkeizaishinbunsha.
Strenz, W. 1986. Historisch-geographische Forschungen in der $D D R$. Gotha: VEB Hermannm Haack. Tietze, W. Boesler, K. A., Klink, H. J. and Voppel, G. eds. 1990. Geographie Deutschlands. Stuttgart: Gebrüder Bornträger.

Weidenfeld, W. and Zimmermann, H. 1990. Deutschland-Handbuch. Berlin: Bundeszentrale für politische Bildung.

Zimmerling, D. and Blase, D. 1993. Berlin. Braunschweig: Westermann. 